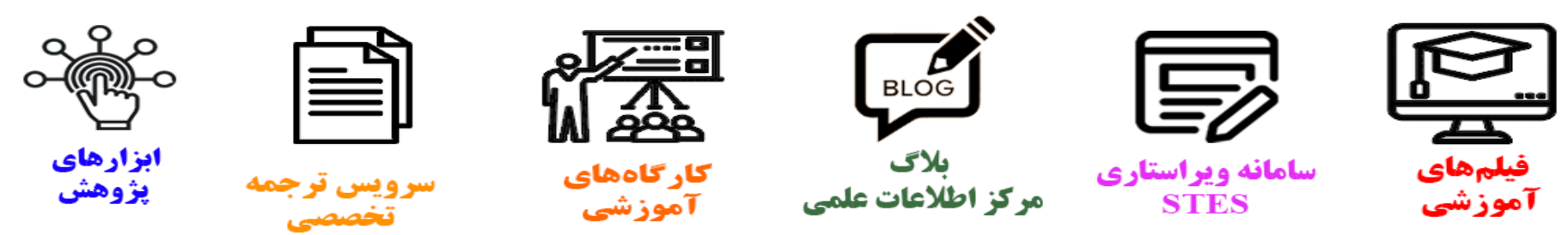

\title{
(c)
}

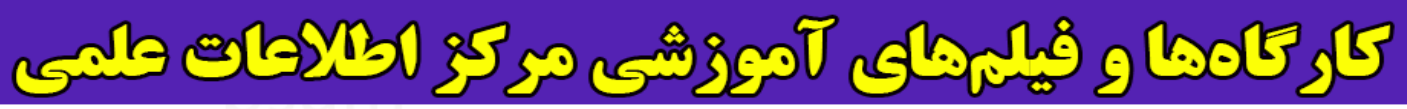
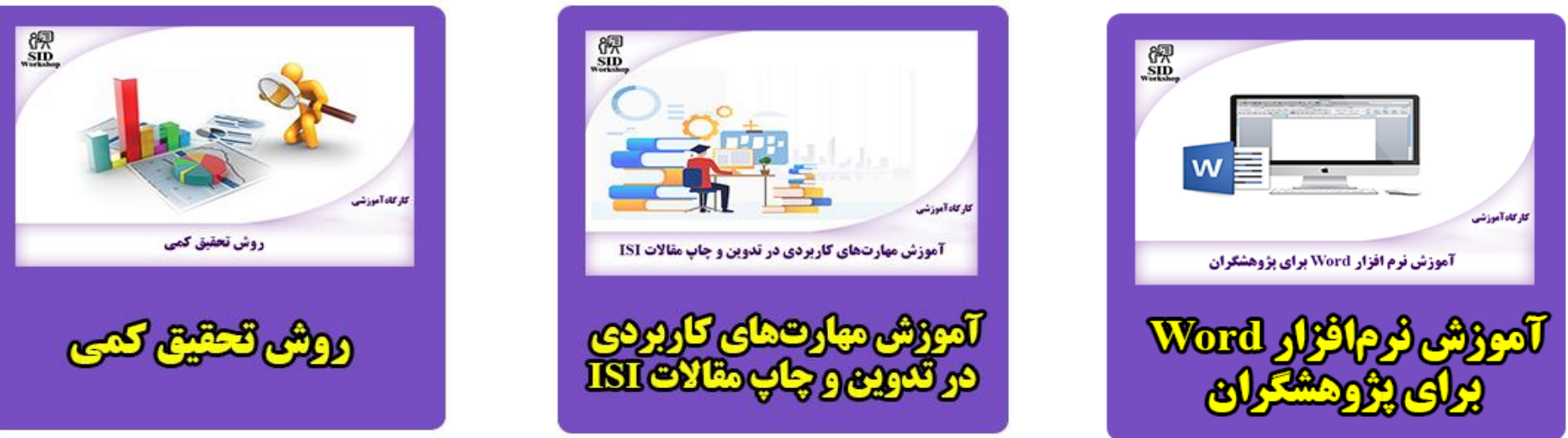


\title{
International Journal of Engineering
}

Journal Hom e page: ww w. ije.ir

\section{Analysis of Photovoltaic Module Resistance Characteristics}

\author{
L. Pan* \\ School of Control and Mechanical Engineering, Tianjin Institute of Urban Construction, and Control Science and Engineering School, HeBei \\ University of Technology, 300130, Tianjin, China
}

\section{PAPER INFO}

Paper history:

Received 02 December 2012

Received in revised form 22 February 2013

Accepted 16 May 2013

Keywords:

PV Module

Diode

Serial Resistance

Parallel Resistance

\author{
$A B S T R A C T$
}

This paper proposes a novel analysis method for inner resistances of photovoltaic (PV) module. The main objectives are to obtain the resistance parameters of PV modules by adjusting I-V equation and voltage equation of diode and to find the relationship between resistance parameters and power. Firstly, values of serial and parallel resistance at maximum power point are concluded. Secondly, the curves of serial and parallel resistance are obtained when load increased from zero to infinity. Thirdly, the relationship between parallel resistance and power is obtained and the influence caused by ignorance of resistances is analyzed. Finally, simulation and experimental results of photovoltaic module show that the method is correct and feasible.

\section{INTRODUCTION}

Equivalent circuit is a basic method for PV cell feature description, and a single-diode model of PV cell is shown in Figure 1, which is composed by an ideal current source $I_{g}$, an ideal diode $\mathrm{D}$, serial resistance $R_{s}$ and parallel resistance $R_{p}[1,2]$. Some more sophisticated models are proposed by other authors for further consideration. For example, an extra diode is used to represent the effect of the carrier recombination in [3-7]. A three-diode model is used in [8] to further consider other neglected influences in [3-7]. In this paper, single diode model, which has an excellent compromise between accuracy and simplicity, is used for analysis and study of PV cell in Figure 1. Lots of authors omit the parallel resistance during study or discussion of PV cell characteristic, and only consider the influence caused by serial resistance change on PV system output [9-13]. Since the serial resistance is small, it is regarded as short-circuited [14-16] for acquiring a simple model, and the influence on output caused by this simplicity on different working conditions has not been analyzed. In fact, it is one-toone correspondence between value of parallel resistance and value of serial resistance and the negligence of serial resistance or parallel resistance will increase

\footnotetext{
${ }^{1 *}$ Corresponding Author Email: panlei4089@163.com (L. Pan)
}

inaccuracy of PV cell model. This paper researches the changing rule of serial and parallel resistance, and studies the relationship between parallel resistance and output power. In addition, the influence on output caused by negligence of serial or parallel resistance in different working areas has also been analyzed. Simulation and experiment results have proven the correctness of obtained conclusion.

\section{PV CELL MODEL}

The single-diode model of PV cell is shown in Figure 1, and the mathematical model of ideal PV cell is shown as Equation (1). However, Equation (1) is not sufficient for describing $I-V$ characteristic of PV cell, which also includes some other factors. Equation (2) is used to describe the $I-V$ characteristic of actual PV cell shown in Figure $1[1,2]$.

$$
\begin{aligned}
& I_{c}=I_{g}-I_{s a t}\left\{\exp \left(\frac{V_{c}}{V_{k T}}\right)-1\right\} \\
& I_{c}=I_{g}-I_{\text {sat }}\left\{\exp \left(\frac{V_{c}+R_{s} I_{c}}{V_{k T}}\right)-1\right\}-\frac{V_{c}+R_{s} I_{c}}{R_{p}}
\end{aligned}
$$

where, $I_{c}$ - current of PV cell, A; $I_{g}$ - light-generated current, A; $I_{\text {sat }}$ - diode reverse saturation current, A; 


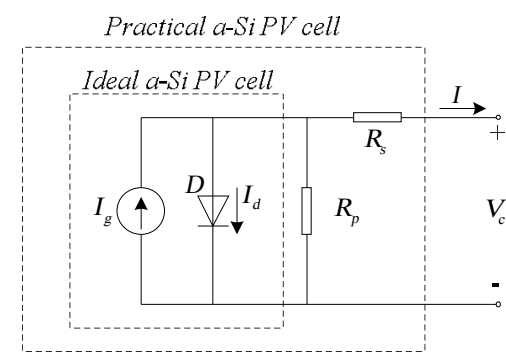

Figure 1. Single diode model of PV cell

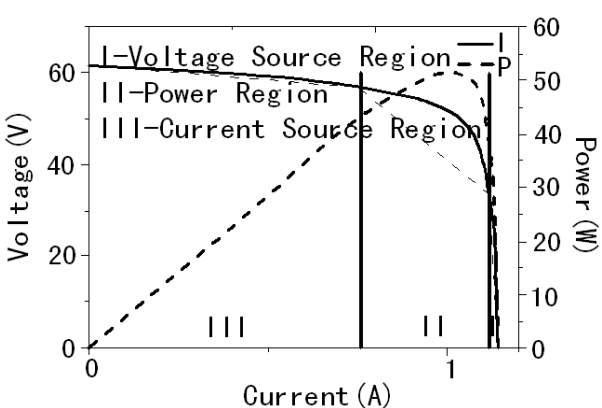

Figure 2. $I-V$ and $I-P$ characteristic of $P V$ cell

$V_{c}$-voltage of PV cell, $V ; V_{k T}=A k T / q ; A$-ideality factor; $k$-Boltzmann's constant, $1.38 \times 10^{-23} \mathrm{~J} / \mathrm{K} ; T$ - the ambient temperature, ${ }^{\circ} \mathrm{C} ; q$ - electron charge, $1.6 \times 10^{-19} C ; R_{s}$ - serial resistance of PV cell, $\Omega ; R_{p}$ - parallel resistance of PV cell, $\Omega$.

I-V characteristic of PV cell under various conditions could be obtained through (2), and one I-V characteristic curve is shown in Figure 2.

Electric generators are generally regarded as current or voltage sources. The practical PV cell presents a complex behavior, which may be current or voltage source depending on different operating condition, and the reason is the change of inner resistances, as shown in Figure 2. In fact, in practical PV device, there is contact resistance on contact surface produced during cell fabrication process between electrode and silicon slice, and there are also substrate resistance and sheet resistance in PV cell. Since these resistances are connected in series with load during normal operation, they are called serial resistance. The short-circuit current of PV cell could be increased through reducing serial resistance $[1,17]$. Rp represents any parallel highconductivity paths across the solar cell $\mathrm{p}$-n junction or on the cell edges. These would be due to crystal damage and impurities in and near the junction and give rise to the shunt current $[18,19]$. These shunt paths lead currents away from the intended load and their effects are detrimental to the module performance especially at low intensity levels. The maximum power efficiency will be reduced if $\mathrm{Rp}$ is too small.

In Figure 2, I-V and I-P curves of PV cell could be divided into three regions according to changing characteristic of curves, namely: 1) the current-source region; 2) the power region; and 3) the voltage-source region. Output characteristics of PV cell are completely different on different regions, but the amount of energy absorbed by PV cell from solar light is certain during a certain time, which shows that the inner consumption of PV cell varies at different regions or that the inner resistance varies with the change of output.

Environment plays an important role on output characteristic of PV cell, and the following formulas show the influence of solar irradiance and temperature on PV cell parameters [16, 20-22].

$$
\begin{aligned}
& I_{g}=\frac{G}{G_{\text {std }}} I_{g s t d}+J_{0}\left(T_{c}-T_{\text {std }}\right) \\
& I_{d}=I_{0}\left[\exp \left(\frac{U_{d}}{V_{k T}}\right)-1\right] \\
& I_{0}=I_{\text {dstd }}\left(\frac{T_{c}}{T_{s t d}}\right)^{3} \exp \left[\frac{q E_{g}}{b k}\left(\frac{1}{T_{s t d}}-\frac{1}{T_{c}}\right)\right] \\
& E_{g}=1.16-7.02 \times 10^{-4} \frac{T_{c}^{2}}{T_{c}+1108} \\
& T_{c}=273+T+\left(\frac{N O C T-20}{0.8}\right) G
\end{aligned}
$$

where, $G$-solar irradiance on cell surface, $\mathrm{kW} / \mathrm{m}^{2}$; $G_{\text {std }}$-nominal solar irradiance, $1 \mathrm{~kW} / \mathrm{m}^{2} ; I_{\text {gstd }}$ - lightgenerated current at nominal condition (usually 25 and $\left.1 \mathrm{~kW} / \mathrm{m}^{2}\right), A ; J_{0}$ - temperature coefficient of lightgenerated current; $T_{c}$ - the absolute temperature of the cell; $T_{\text {std }}$-absolute temperature at nominal condition, $K ; I_{d}$-diode current, A; $I_{0}$ - diode reverse saturation current; $U_{d}$ - diode voltage; $I_{\text {dstd }}$-diode current at reference temperature (25), A; $E_{g}-$ bandgap energy, $\mathrm{eV} ; b$-ideality factor; NOCTnominal operating cell temperature $\left({ }^{\circ} \mathrm{C}\right)$.

\section{PV MODULE MODEL}

Generally, a commercial PV module usually consists of several similar PV cells connected in series to obtain a high output voltage or a large output current. For a module that is composed by $\mathrm{m}$ serial connected PV cells, it could be analyzed through using single diode model shown in Figure 3, and the $I-V$ characteristic equation $[1,23]$ of $\mathrm{PV}$ module is shown as follow:

$I_{m}=I_{g m}-I_{0 m}\left\{\exp \left[\frac{V_{m}+I_{m} R_{s m}}{V_{k T m}}\right]-1\right\}-\frac{V_{m}+I_{m} R_{s m}}{R_{p m}}$

where, $I_{m}$-current of module, A; $I_{g m}$ - light- 
generated current of module, $I_{g m}=m I_{g} ; m$-number of cells connected in series in a PV module; $I_{0 m}=m I_{0}$; $V_{m}$-voltage of module, $V ; V_{k T m}=m V_{k T} ; R_{s m}$-serial resistance of module equivalent circuit, $R_{s m}=m R_{s}$; $R_{p m}$-parallel resistance of module equivalent circuit, $R_{p m}=m R_{p}$.

Serial resistance and parallel resistance are usually come in pairs, and defined as follow.

$R_{p m}=\left(V_{m}+I_{m} R_{s m}\right) /\left\{I_{g m}-I_{0 m}\left[\exp \left(\frac{V_{m}+I_{m} R_{s m}}{V_{k T m}}\right)-1\right]-I_{m}\right\}$

\section{IMPEDANCE CALCULATIONS}

As shown in Figure 3, the voltage drop of equivalent diode at maximum power point could be calculated through Equation (10):

$V_{d m}=V_{m m}+I_{m m} R_{s m}$

where, $V_{d m}$-diode voltage in module; $V_{m m}$-voltage of module at maximum power point, $V ; I_{m m}$-current of module at maximum power point, $\mathrm{A}$.

The following equation could be acquired from diode characteristic:

$$
I_{d m}=I_{0 m}\left[\exp \left(\frac{V_{d m}}{V_{k T m}}\right)-1\right]
$$

where, $I_{d m}$ - diode current in module, A.

Hence:

$$
V_{d m}=V_{k T m} \ln \left(I_{d m} / I_{0 m}+1\right)
$$

Equation (13) could be obtained after combining Equation (10) and Equation (12).

$$
V_{m m}+I_{m m} R_{s m}=V_{k T m} \ln \left(I_{d m} / I_{0 m}+1\right)
$$

Only one variable $R_{s m}$ is unknown in Equation (13), and equivalent serial resistance could be obtained through this formula. Calculation method is described as follow:

(1) carry out serial expansion for Equation (11):

$$
I_{d m}=I_{0 m}\left[\frac{V_{d m}}{V_{k T m}}+\frac{1}{2 !}\left(\frac{V_{d m}}{V_{k T m}}\right)^{2}+\ldots+\frac{1}{n !}\left(\frac{V_{d m}}{V_{k T m}}\right)^{n}+\ldots\right]
$$

(2) substitute Equation (10) into Equation (14):

$$
\begin{aligned}
& I_{d m}=I_{0 m}\left[\frac{V_{m m}+I_{m m} R_{s m}}{V_{k T m}}+\frac{1}{2 !}\left(\frac{V_{m m}+I_{m m} R_{s m}}{V_{k T m}}\right)^{2}\right. \\
& \left.+\ldots+\frac{1}{n !}\left(\frac{V_{m m}+I_{m m} R_{s m}}{V_{k T m}}\right)^{n}+\ldots\right]
\end{aligned}
$$

(3) substitute Equation (15) into Equation (13):

$$
\begin{aligned}
& V_{m m}+I_{m m} R_{s m}=V_{k T} \ln \left[1+\frac{V_{m m}+I_{m m} R_{s m}}{V_{k T m}}+\right. \\
& \left.\frac{1}{2 !}\left(\frac{V_{m m}+I_{m m} R_{s m}}{V_{k T m}}\right)^{2}+\ldots+\frac{1}{n !}\left(\frac{V_{m m}+I_{m m} R_{s m}}{V_{k T m}}\right)^{n}+\ldots\right]
\end{aligned}
$$

(4) Error is introduced.

$$
\begin{aligned}
& \text { Erro }_{R s}=V_{m m}+I_{m m} R_{s m}-V_{k T m} \ln \left[1+\frac{V_{m m}+I_{m m} R_{s m}}{V_{k T m}}+\right. \\
& \left.\frac{1}{2 !}\left(\frac{V_{m m}+I_{m m} R_{s m}}{V_{k T m}}\right)^{2}+\ldots+\frac{1}{n !}\left(\frac{V_{m m}+I_{m m} R_{s m}}{V_{k T m}}\right)^{n}+\ldots\right]
\end{aligned}
$$

If $\mathrm{n}$ is large enough, and $I_{m m} R_{s m}<<V_{m m}$, Equation (18) is established.

$\varepsilon=\frac{1}{n !}\left(\frac{V_{m}}{V_{k T m}}\right)^{n} \approx \frac{1}{n !}\left(\frac{V_{m}+I_{m m} R_{s m}}{V_{k T m}}\right)^{n}$

If $\varepsilon$ is smaller than a set value $\varepsilon_{0}, \mathrm{n}$ could be determined from Equation (18). $R_{s m}$ at this point could be obtained if error satisfies requirement.

Similarly, through appropriately increasing or decreasing value of $R_{s m}$, if Erro $_{R s}$ is smaller than a set value Erro $_{s s e t}, R_{s m}$ could be determined.

The detail iterative process is shown in Figure 4. Iterative error curve of serial resistance at maximum power point is shown in Figure 5.

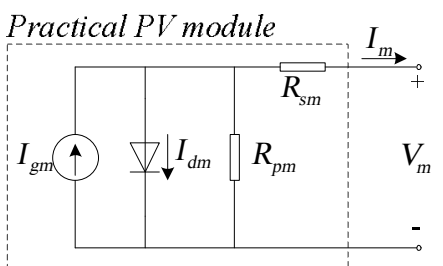

Figure 3. Circuit model of PV module

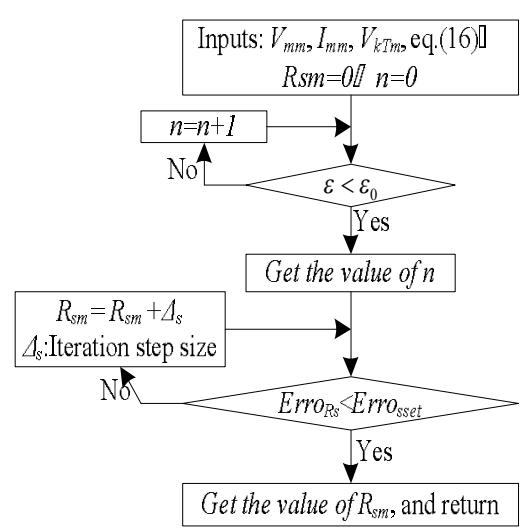

Figure 4. Iterative calculation chart of $R_{s m}$ at maximum power point 


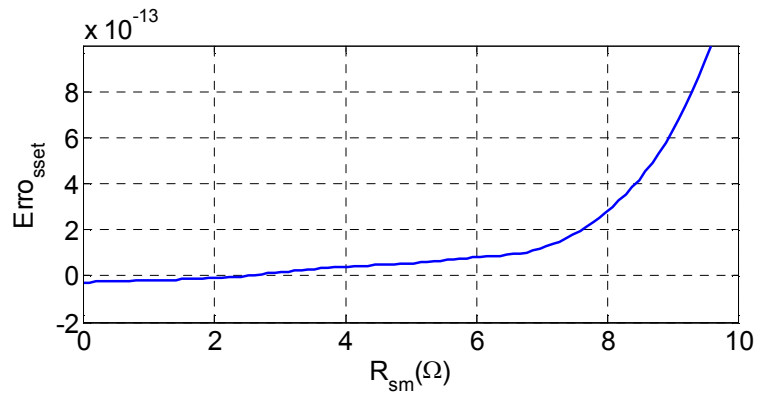

Figure 5. Error curve of serial resistance

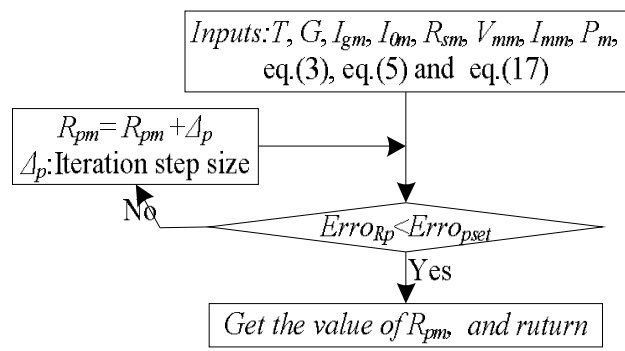

Figure 6. Iterative calculation chart of $R_{p m}$ at maximum power point

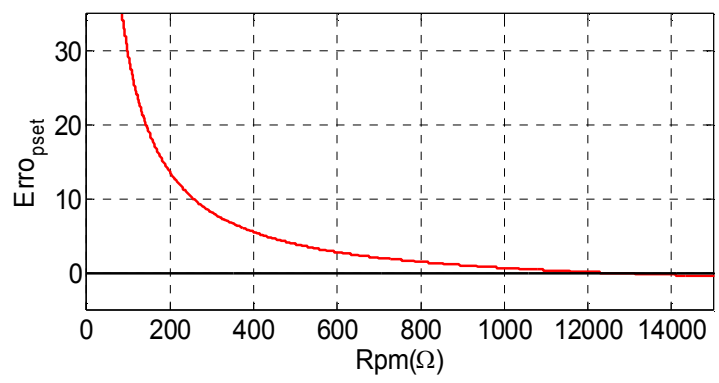

Figure 7. Error curve of parallel resistance

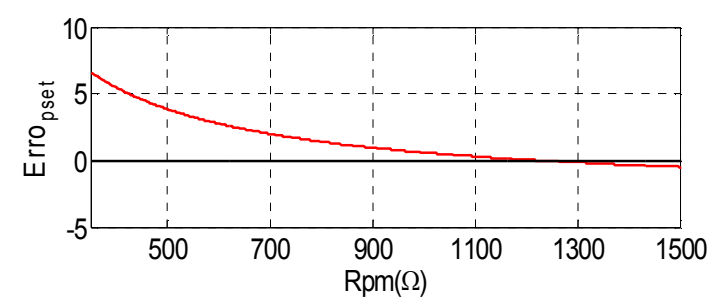

Figure 8. Impedance analysis curve of PV module

TABLE 1. Tested PV module parameters

\begin{tabular}{llll}
\hline Isc & $1.23 \mathrm{~A}$ & $\mathrm{~K}_{\mathrm{V}}$ & $-0.28 \% / \mathrm{K}$ \\
$\mathrm{Voc}$ & $61.21 \mathrm{~V}$ & $\mathrm{~K}_{\mathrm{I}}$ & $0.09 \% / \mathrm{K}$ \\
$\mathrm{Ipm}$ & $1.02 \mathrm{~A}$ & $\mathrm{I}_{\mathrm{gms}}$ & $1.29 \mathrm{~A}$ \\
$\mathrm{Vpm}$ & $47.1 \mathrm{~V}$ & $\mathrm{I}_{0 \mathrm{~ms}}$ & $5.36 * 10^{-15} \mathrm{~A}$ \\
$\mathrm{Pm}$ & $48.02 \mathrm{~W}$ & $\mathrm{Am}$ & 1.8 \\
\hline
\end{tabular}

TABLE 2. Calculation parameter and result of resistance iteration at maximum power point

\begin{tabular}{cccccccc}
\hline $\boldsymbol{V}_{\boldsymbol{m}}$ & $\boldsymbol{I}_{\boldsymbol{m}}$ & $\boldsymbol{P}_{\boldsymbol{m}}$ & $\boldsymbol{n}$ & $\boldsymbol{R}_{\boldsymbol{s m}}$ & $\boldsymbol{R}_{\boldsymbol{p m}}$ & $\boldsymbol{\Delta}_{\boldsymbol{s}}$ & $\boldsymbol{\Delta}_{\boldsymbol{p}}$ \\
\hline 48.01 & 1.019021 & 48.97 & 85 & 2.19 & 1201 & 0.001 & 0.1 \\
\hline
\end{tabular}

After obtaining serial resistance $R_{s m}$, the parallel resistance $R_{p m}$ of this point could be calculated through iteration shown in Equation (19). If error requirement could be satisfied, parallel resistance of this point could be obtained, and detail iterative process is shown in Figure 6. Iterative error curve of parallel resistance at maximum power point is shown in Figure 7.

$$
\begin{aligned}
& \text { Erro }_{R p}=P_{m}-V_{m m}\left\{I_{g m}-I_{0 m}\left[\exp \left(\frac{V_{m m}+I_{m m} R_{s m}}{V_{k T m}}\right)-1\right]\right. \\
& \left.-\frac{V_{m m}+I_{m m} R_{s m}}{R_{p m}}\right\}
\end{aligned}
$$

PV module parameters are shown in Table 1. Calculation parameters and results are shown in Table 2. As shown in Table 2 and Figure 7, parallel resistance is large at maximum power point, and hence, how to reasonably select initial value of iteration for reducing iterative process is an inevitable problem. In Equation (9), if PV module is open-circuit, parallel resistance could be calculated through Equation (20), which is an equation with one unknown, and $R_{p m}$ of this point could be directly calculated out through substituting values of $V_{\text {moc }}, I_{g m}, I_{0 m}$ and $V_{k T m}$. This value of $R_{p m}$ could be used as initial iterative value for calculation of parallel resistance, and iterative error curve is shown in Figure 8.

$$
R_{p m}=V_{m o c} /\left\{I_{g m}-I_{0 m}\left[\exp \left(\frac{V_{m o c}}{V_{k T m}}\right)-1\right]\right\}
$$

where, $V_{\text {moc }}$-open-circuit voltage of module, $V$.

Based on above analysis, if output voltage and current at each moment of PV module could be obtained, serial resistance and parallel resistance at each moment could also be obtained. Iterative Equation (21) and Equation (22) for serial resistance and parallel resistance at each moment could be obtained through using Equation (17) and Equation (19), and detailed iterative processes are shown in Figures 9 and 10.

$$
\begin{aligned}
& \text { Erro }_{R s}^{\prime}=V_{m}+I_{m} R_{s m}-V_{k T m} \ln \left[1+\frac{V_{m}+I_{m} R_{s m}}{V_{k T m}}+\right. \\
& \left.\frac{1}{2 !}\left(\frac{V_{m}+I_{m m} R_{s m}}{V_{k T m}}\right)^{2}+\ldots+\frac{1}{n !}\left(\frac{V_{m}+I_{m} R_{s m}}{V_{k T m}}\right)^{n}\right] \\
& \text { Erro }{ }_{R p}=P_{m}-V_{m}\left\{I_{g m}-I_{0 m}\left[\exp \left(\frac{V_{m}+I_{m} R_{s m}}{V_{k T m}}\right)-1\right]\right. \\
& \left.-\frac{V_{m}+I_{m} R_{s m}}{R_{p m}}\right\}
\end{aligned}
$$




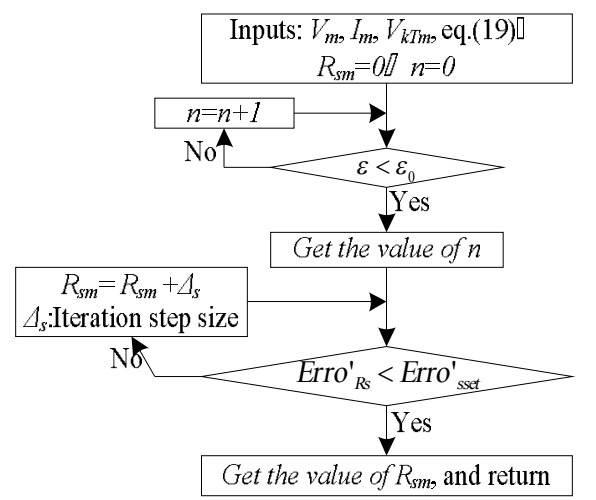

Figure 9. Iterative chart for serial resistance

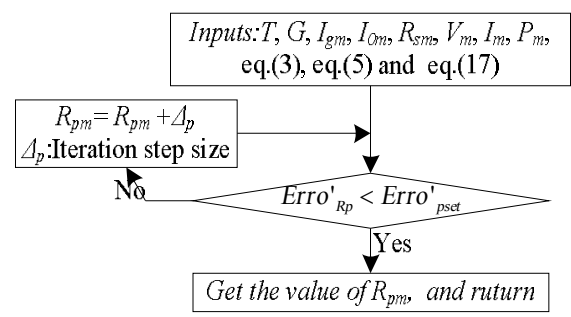

Figure 10. Iterative chart for parallel resistance

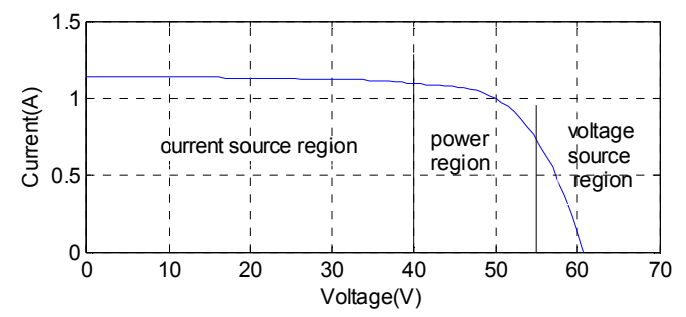

Figure 11. I-V simulation curve

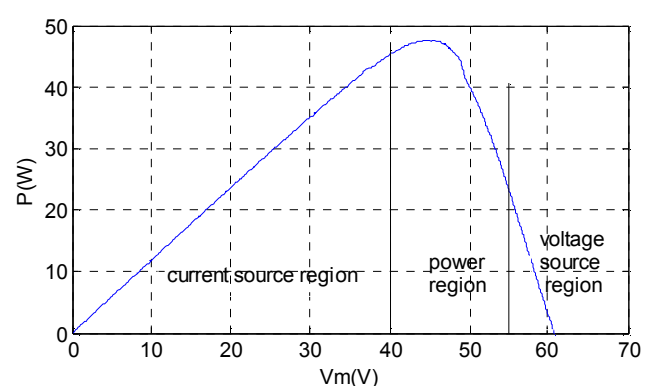

Figure 12. P-V simulation curve

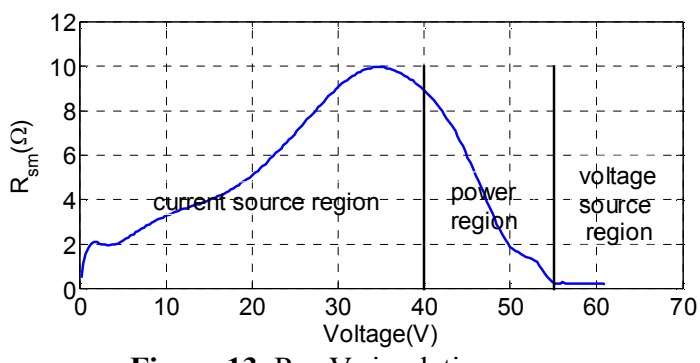

Figure 13. $\mathrm{R}_{\mathrm{sm}}-\mathrm{V}$ simulation curve

\section{SIMULATION AND EXPERIMENT RESULTS}

Based on above method, simulation results for PV module are shown in Figure 11 14 $\quad(n=85$ , $\mathrm{T}=25$, solar irradiance is $1000 \mathrm{~W} / \mathrm{m}^{2}$ ).

Based on above method, experimental system has been built and shown in Figure 15. Experimental results are shown in Figures 16 to 21.

Experimental and simulation curves show that:

In Figures 13, 14, 16, and 17, serial resistance and parallel resistance change with change of module output voltage, and there are maximum values in their curves. Under same output voltage, parallel resistance decreases with increase of temperature and increases with rise of irradiance as shown in Figures 19 and 21, and serial resistance increases with increase of temperature and decreases with rise of irradiance as shown in Figures 18 and 20. In Figures 18 to 21, maximum values of serial resistance and parallel resistance will move to left with increase of temperature and move to right with increase of irradiance.

In Figures 13 and 17, output voltage at maximum value of serial resistance is about $1 / 2$ of open-circuit voltage. Equivalent serial resistance increases when output current of module decreases little and it begins to decline when current significantly decreases as shown in Figures 11, 13 and 17. In Figures 12, 14 and 16, parallel resistance increases with increase of output power and decreases with decrease of output power, and change rate of parallel resistance is large in power region and there is a maximum value. Parallel resistance reaches its maximum value when output power reaches its maximum, and it varies little when output voltage approaches open-circuit voltage as shown in Figures 12, 14 and 16.

In Figures 12, 14 and 16, since parallel resistance increase gradually in current source region, inner consumption of module gradually decreases, and output power gradually increases; since parallel resistance is large in power region, inner consumption of module is small and output power is large; in voltage source region, parallel resistance of module decrease gradually, inner consumption increases gradually, and output power decreases gradually. Based on above analysis, negligence of parallel resistance has least affect on module output in power region.

In Figures 11, 13 and 17, since current output is high and output voltage is small in current source region, voltage drop on parallel resistance differs little from output voltage. There will be great affect on module output if ignore serial resistance. The curve characteristic of upper half part of power region is similar to that of current source region, but in rear half part, since the voltage drop of serial resistance is greatly smaller than output voltage of module, ignorance of serial resistance has little affect on output characteristic 
of module. Curve characteristic of voltage source is similar to that of rear half part of power region. Hence, ignorance of serial resistance has little affects on output characteristic in rear half part of power region and voltage source region.

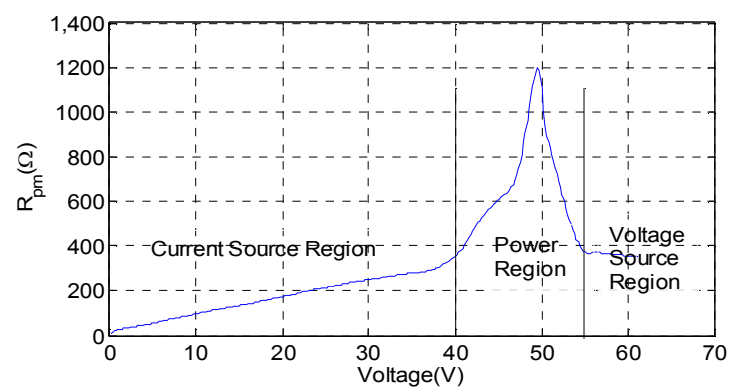

Figure 14. $R_{p}-V$ simulation curve

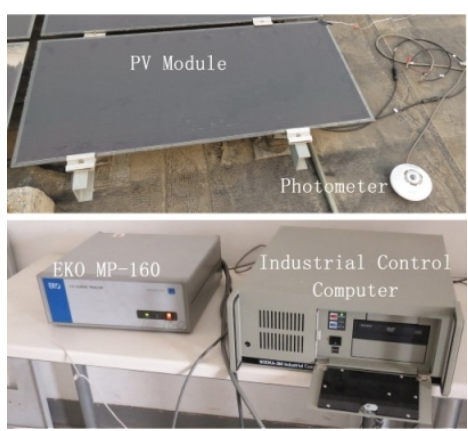

Figure 15. Test system

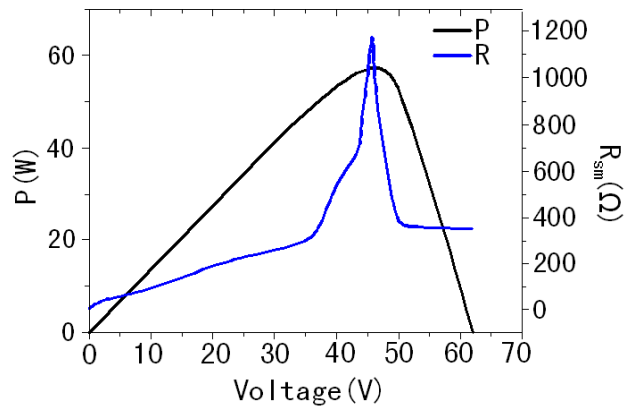

Figure 16. $P-V$ and $R_{p}-V$ curves

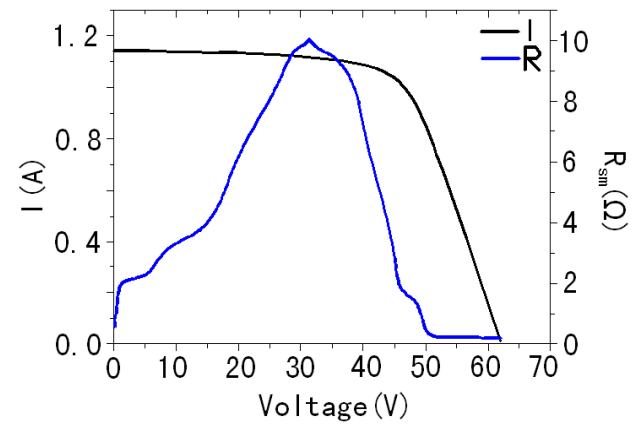

Figure 17. $I-V$ and $R_{s}-V$ curves

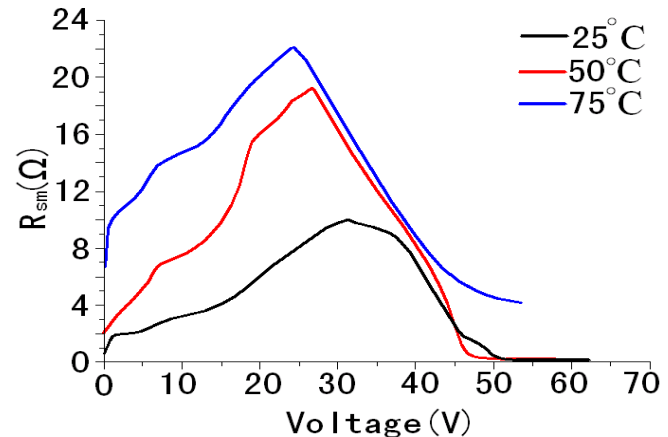

Figure 18. $\mathrm{R}_{\mathrm{s}}-\mathrm{V}$ experiment curves under different temperature

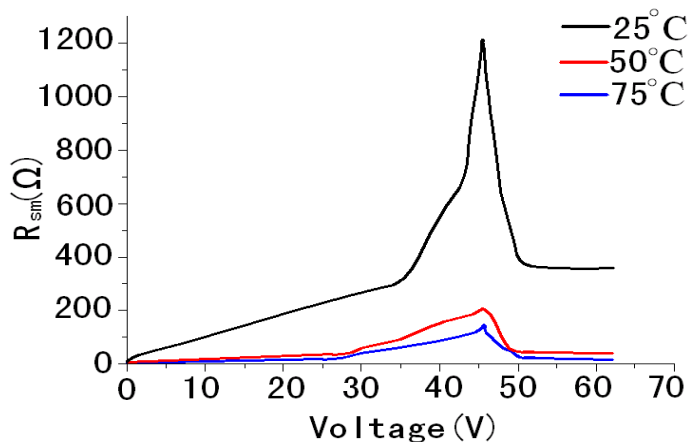

Figure 19. $\mathrm{R}_{\mathrm{p}}-\mathrm{V}$ experiment curves under different temperature

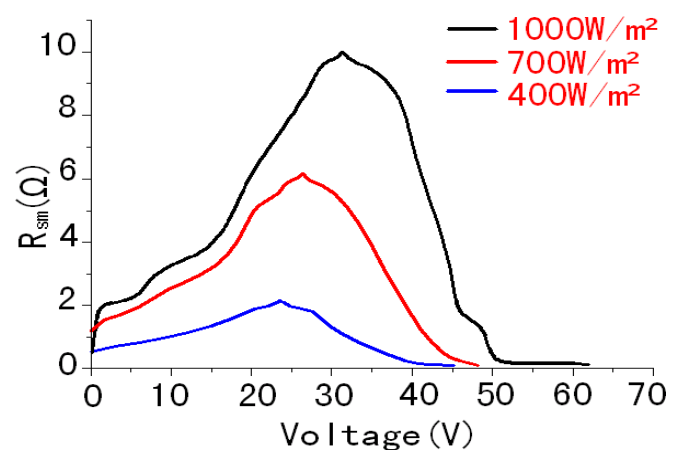

Figure 20. $\mathrm{R}_{\mathrm{s}}-\mathrm{V}$ experimental curves under different irradiance

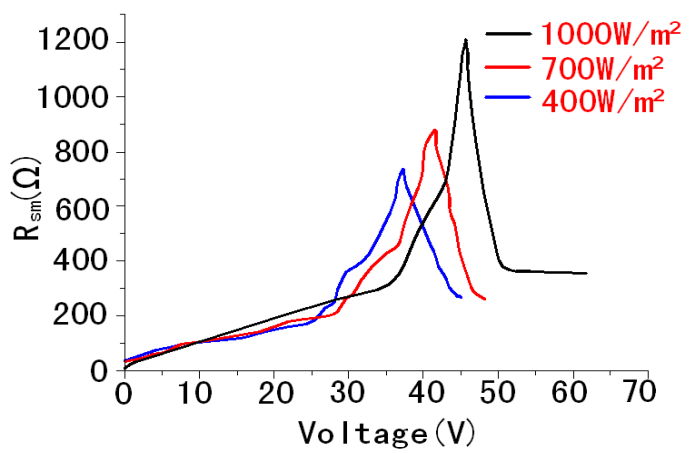

Figure 21. $\mathrm{R}_{\mathrm{p}}-\mathrm{V}$ experimental curves under different irradiance 


\section{CONCLUSION}

Based on the detail analysis of single diode model of module, the paper proposes an iterative method for serial and parallel resistance, obtains characteristic curves for serial and parallel resistance, discoveries changing regularity of them with different temperature and irradiance, analyzes relationship between parallel resistance and output power of module. It also detailedly discusses the influence on output characteristics caused by simplicity on module model (ignorance of serial resistance and parallel resistance). The paper provides important information on simulation and analysis of single diode model. Above conclusion provides reference for model establishment simulation and system design of other kinds PV modules.

\section{ACKNOWLEDGMENT}

This work was supposed by Universities Science and Technology Fund Planning Project of Tianjin (20100713).

\section{REFERENCES}

1. Li, J., Yu, H., Wong, S. M., Li, X., Zhang, G., Lo, P. G.-Q., and Kwong, D.-L., "Design guidelines of periodic si nanowire arrays for solar cell application", Applied Physics Letters, Vol. 95, No. 24, (2009).

2. Sharifi, M. and Adibi, A., "Semiconductor device simulation be a new method of solving poisson, laplace and schrodinger equations", International Journal Of Engineering, Vol. 13, No. 1, (2000), 89-97.

3. Jenifer, A., Newlin, N., Rohini, G. and Jamuna, V., "Development of matlab simulink model for photovoltaic arrays", in Computing, Electronics and Electrical Technologies (ICCEET), International Conference on, IEEE. (2012), 436-442.

4. Rahmani, R., Fard, M., Shojaei, A., Othman, M. and Yusof, R., "A complete model of stand-alone photovoltaic array in matlabsimulink environment", in Research and Development (SCOReD), Conference on, IEEE, (2011), 46-51.

5. Pongratananukul, N. and Kasparis, T., "Tool for automated simulation of solar arrays using general-purpose simulators", in Computers in Power Electronics, 2004. Proceedings. Workshop on, IEEE, (2004), 10-14.

6. Chowdhury, S., Taylor, G., Chowdhury, S., Saha, A. and Song, Y., "Modelling, simulation and performance analysis of a pv array in an embedded environment", in Universities Power Engineering Conference, UPEC 42nd International, IEEE (2007), 781-785.

7. Hyvarinen, J. and Karila, J., "New analysis method for crystalline silicon cells", in Photovoltaic Energy Conversion, 2003. Proceedings of 3rd World Conference on, IEEE. Vol. 2, No., (2003), 1521-1524.

8. Nishioka, K., Sakitani, N., Uraoka, Y. and Fuyuki, T., "Analysis of multicrystalline silicon solar cells by modified 3-diode equivalent circuit model taking leakage current through periphery into consideration", Solar Energy Materials and Solar Cells, Vol. 91, No. 13, (2007), 1222-1227.

9. Xiao, W., Dunford, W. G. and Capel, A., "A novel modeling method for photovoltaic cells", in Power Electronics Specialists Conference, PESC 04. 35th Annual, IEEE. Vol. 3, No., (2004), 1950-1956.

10. Carrero, C., Amador, J. and Arnaltes, S., "A single procedure for helping pv designers to select silicon pv modules and evaluate the loss resistances", Renewable Energy, Vol. 32, No. 15, (2007), 2579-2589.

11. Ahmad, G., Hussein, H. and El-Ghetany, H., "Theoretical analysis and experimental verification of PV modules", Renewable Energy, Vol. 28, No. 8, (2003), 1159-1168.

12. Laird, I. and Lu, D., "High step-up DC/DC topology and mppt algorithm for use with a thermoelectric generator", (2013).

13. Veerachary, M., "Psim circuit-oriented simulator model for the nonlinear photovoltaic sources", IEEE Transactions on Aerospace and Electronic Systems, Vol. 42, No. 2, (2006), 735-740.

14. Kajihara, A. and Harakawa, A., "Model of photovoltaic cell circuits under partial shading", in Industrial Technology, ICIT IEEE International Conference on, IEEE, (2005), 866-870.

15. Benavides, N. D. and Chapman, P. L., "Modeling the effect of voltage ripple on the power output of photovoltaic modules", Industrial Electronics, IEEE Transactions on, Vol. 55, No. 7, (2008), 2638-2643.

16. Xiao, W., Edwin, F. F., Spagnuolo, G. and Jatskevich, J., "Efficient approaches for modeling and simulating photovoltaic power systems", Photovoltaics, IEEE Journal of, Vol. 3, No. 1, (2013), 500-508.

17. Pasquinelli, M. and Barakel, D., "Serial resistance effect on ptype and n-type silicon concentrated solar cells", in Clean Electrical Power (ICCEP), International Conference on, IEEE., (2011), 161-163.

18. Hacke, P., Gee, J., Kumar, P., Howarth, J., Gonzales, V., Pratt, L., Strumpel, C., Dominguez, J., Franklin, J., and Lopez, G., "Optimized emitter wrap-through cells for monolithic module assembly", in Photovoltaic Specialists Conference (PVSC), 34th IEEE, (2009), 2102-2106.

19. Meyer, E. L. and Ernest van Dyk, E., "The effect of reduced shunt resistance and shading on photovoltaic module performance", in Photovoltaic Specialists Conference, Conference Record of the Thirty-first IEEE, (2005), 1331-1334.

20. Ikegami, T., Maezono, T., Nakanishi, F., Yamagata, Y. and Ebihara, K., "Estimation of equivalent circuit parameters of PV module and its application to optimal operation of pv system", Solar Energy Materials and Solar Cells, Vol. 67, No. 1, (2001), 389-395.

21. Barbato, M., Meneghini, M., Giliberto, V., Giaffreda, D., Magnone, P., De Rose, R., Fiegna, C., and Meneghesso, G., "Effect of shunt resistance on the performance of mc-silicon solar cells: A combined electro-optical and thermal investigation", in Photovoltaic Specialists Conference (PVSC), 2012 38th IEEE, (2012), 001241-001245.

22. Mekhilef, S. and Rahim, N., "Generation of three-phase pwm inverter using xilinx fpga and its application for utility connected pv system", International Journal of Engineering, Transactions B: Applications, Vol. 17, No. 3, (2004), 271-276.

23. Paraskevadaki, E. V. and Papathanassiou, S. A., "Evaluation of mpp voltage and power of mc-si pv modules in partial shading conditions", Energy Conversion, IEEE Transactions on, Vol. 26, No. 3, (2011), 923-932. 


\section{Analysis of Photovoltaic Module Resistance Characteristics}

\section{Pan}

School of Control and Mechanical Engineering, Tianjin Institute of Urban Construction, and Control Science and Engineering School, HeBei University of Technology, 300130, Tianjin, China

\section{PAPER INFO}

Paper history:

Received 02 December 2012

Received in revised form 22 February 2013

Accepted 16 May 2013

Keywords:

PV Module

Diode

Serial Resistance

Parallel Resistance

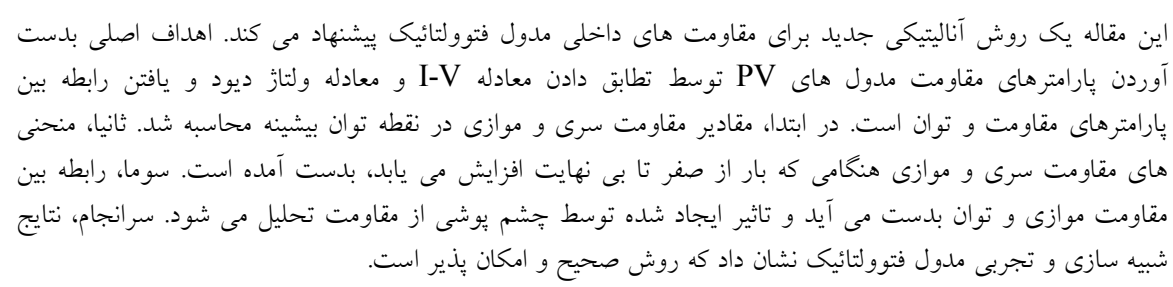

doi: 10.5829/idosi.ije.2013.26.11b.12 


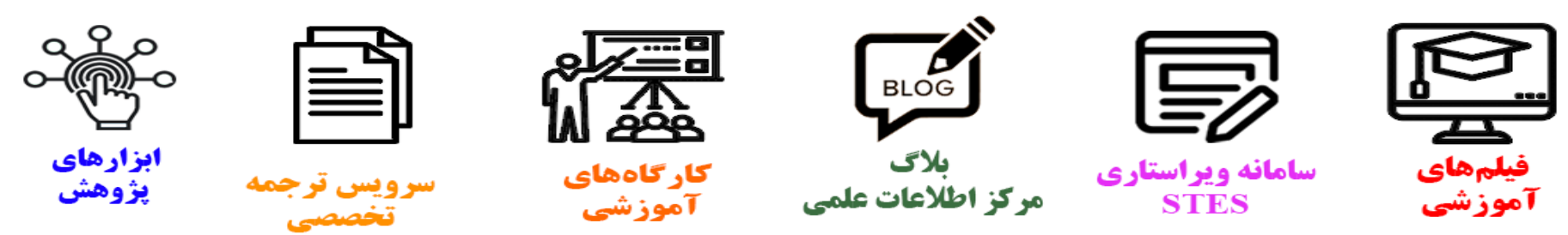

\section{(c)}

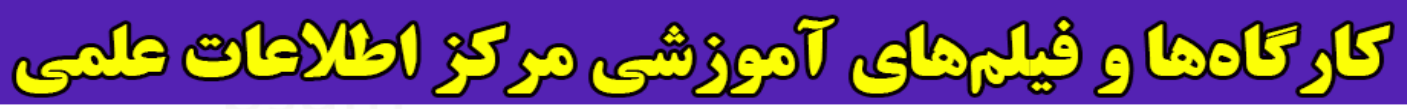
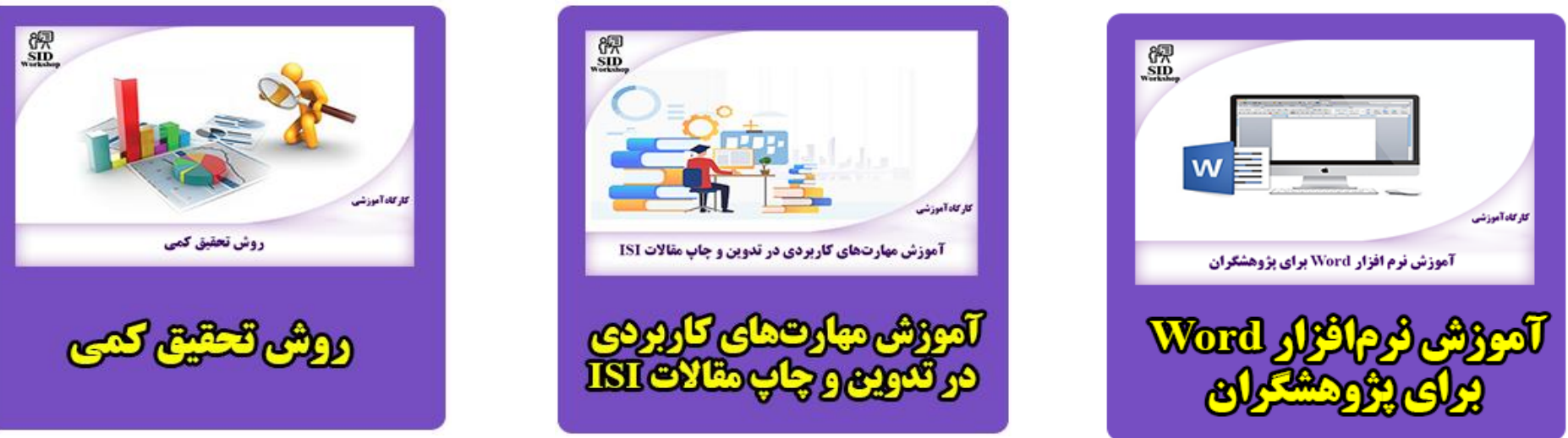